CASE REPORT

\title{
Corticotroph adenoma of the pituitary in a patient with $X$-linked adrenal hypoplasia congenita due to a novel mutation of the DAX-1 gene
}

Ernesto De Menis, Federico Roncaroli ${ }^{1}$, Vladimiro Calvari ${ }^{2}$, Valerio Chiarini ${ }^{3}$, Paolo Pauletto, Giovanna Camerino ${ }^{2}$ and Nadia Cremonini ${ }^{3}$

Department of Internal Medicine, General Hospital, Treviso, Italy, ${ }^{1}$ Department of Neuropathology, Division of Neuroscience and Psychological Medicine Imperial College, Charing Cross Campus, London UK, ${ }^{2}$ Dipartimento di Patologia Umana ed Ereditaria, Sezione di Biologia Generale e Genetica Medica, Università di Pavia, Italy and ${ }^{3}$ Divisione di Endocrinologia, Ospedale Maggiore, Bologna, Italy

(Correspondence should be addressed to E De Menis; Email: edemenis@ulss.tv.it)

\begin{abstract}
Objective: Mutations in the DAX-1 gene result in X-linked congenital adrenal hypoplasia. The classic clinical presentation is primary adrenal insufficiency in early life and hypogonadotropic hypogonadism at the time of expected puberty, but recent data have expanded the phenotypic spectrum of DAX-1 mutations. We report the occurrence of an ACTH-secreting adenoma in a patient with X-linked congenital adrenal hypoplasia.

Design and methods: Detailed clinical, radiological and pathological investigation of the pituitary adenoma. Genomic analysis of the DAX-1 gene in the patient and his mother.

Results: In this patient, primary adrenal failure had been diagnosed at 3 years of age and, despite replacement therapy, at 30 years of age progressive pigmentation developed and impairment of the visual field followed. ACTH was $24980 \mathrm{pg} / \mathrm{ml}$ and nuclear magnetic resonance disclosed a huge pituitary adenoma. Three transsphenoidal operations and radiotherapy were necessary to remove the tumor mass and control ACTH secretion. Histologically, the adenoma was composed of chromophobic and basophilic neoplastic cells with positive immunostaining for ACTH. Moreover, a novel mutation was found both in the patient and his mother: a 4 bp insertion (AGCG) at nucleotide 259, in exon 1 resulting in a frame shift and premature termination.

Conclusions: This case suggests that in adrenal hypoplasia congenita the development of a pituitary adenoma should be considered when a sudden rise of ACTH occurs despite adequate steroid substitution.
\end{abstract}

European Journal of Endocrinology 153 211-215

\section{Introduction}

X-linked adrenal hypoplasia congenita (AHC, OMIM:300200) is characterized by primary adrenal insufficiency and hypogonadotropic hypogonadism. It is caused by mutations of the DAX-1 gene which controls the development of the adrenal and the hypothalamic-pituitary-gonadal axis $(1,2)$.

So-called feedback pituitary adenomas are tumors developing in the setting of the hyperplasia of pituitary cells secondary to untreated primary thyroid, gonadal and adrenal failure (3-5). In these cases the differential diagnosis between hyperplasia and adenoma may be difficult in clinical practice but true adrenocorticotropin hormone (ACTH)-secreting adenomas have occasionally been reported in Addison's disease (6-9).

We report an ACTH-secreting adenoma occurring in a patient with X-linked AHC. This is the first case of association between pituitary adenoma and AHC, furthermore, the patient was found to carry a novel mutation of the DAX-1 gene.

\section{Case report}

A 33-year-old man was admitted for a symptomatic pituitary mass. His parents were alive and in good health, as were his 51-year-old sister and his 20-yearold nephew.

At the age of 3 years, primary adrenal failure was diagnosed during hospitalization for loss of consciousness. From that time sole treatment had been with cortone acetate, the daily dose ranging from 25 to $50 \mathrm{mg}$. The diagnosis was confirmed at the age of 9 years (urinary 17 -hydroxycorticosteroids, $<0.5 \mathrm{mg} / 24 \mathrm{~h}$; 17 -ketosteroids, $1.63 \mathrm{mg} / 24 \mathrm{~h}$; serum dihydroepiandrosteronesulfate (DHEA-S), $0.12 \mu \mathrm{g} / \mathrm{ml}$ ). At the same age he was 
found to have primary hypothyroidism (total thyroxine, $5.37 \mu \mathrm{g} / 100 \mathrm{ml}$ ) which was treated with thyroid extracts. Delayed puberty was diagnosed at the age of 17 years: testosterone was $0.26 \mathrm{ng} / \mathrm{ml}$, basal luteinizing hormone (LH) was $0.55 \mathrm{mIU} / \mathrm{ml}$ and follicle-stimulating hormone (FSH) $0.78 \mathrm{mIU} / \mathrm{ml}$, with a peak after gonadotropin-releasing hormone (GnRH) infusion of 0.92 and $1.23 \mathrm{mIU} / \mathrm{ml}$ respectively. Skull X-rays were negative. For a short period he was treated with human chorionic gonadotropin (HCG) and testosterone undecanoate and thereafter daily nasal puffs of gonadorelin. An adrenal crisis occurred at the age of 29 years during an infection of the upper respiratory airways.

Since the age of 30 years, he has developed progressive skin pigmentation and overweight. At the age of 33 years bilateral superior quadrantopsia occurred. A computed tomography scan revealed a large pituitary mass. On admission, his height was $187 \mathrm{~cm}$ and weight $108 \mathrm{~kg}$ (body mass index (BMI) 30.9) with abdominal distribution of fat. Only scanty pubic hair (P2) was present and the penis was short with slight hypospadia. Testicular volume was $3 \mathrm{ml}$ bilaterally. Hyper-pigmentation of the skin and buccal mucosa was easily evident. Therapy at that time was cortone acetate 25 t.i.d. (thrice in die), Tiroide Vister (extracts of thyroid), and nasal gonadorelin. Routine blood tests were normal. Serum testosterone was $0.2 \mathrm{ng} / \mathrm{ml}$, basal FSH and LH were both $0.1 \mathrm{mIU} / \mathrm{ml}$ with no response to $100 \mu \mathrm{g}$ i.v. of GnRH. Serum-free thyroxine was $0.61 \mathrm{ng} / 100 \mathrm{ml}$ and thyroid-stimulating hormone (TSH) $16.3 \mathrm{mIU} / \mathrm{l}$. Antibodies against thyroid peroxidase, thyroglobulin and adrenals were negative. Serum prolactin was $19 \mathrm{ng} / \mathrm{ml}$, growth hormone $(\mathrm{GH}$; mean of four 30 minutes samples) was less than $0.1 \mathrm{ng} / \mathrm{ml}$ and insulin-like growth factor-I (IGF-I) was $103 \mathrm{ng} / \mathrm{ml}$ (normal values 110-465). Alpha-subunits were $0.3 \mathrm{IU} / \mathrm{l}$ (normal values 0.1-0.5). Despite replacement therapy, serum ACTH concentration was $24980 \mathrm{pg} / \mathrm{ml}$. After withdrawal of cortone for $24 \mathrm{~h}$, serum cortisol was less than $0.2 \mu \mathrm{g} / 100 \mathrm{ml}$, DHEA-S less than $300 \mathrm{ng} / \mathrm{ml}$, 17-hydroxyprogesterone less than $0.1 \mathrm{ng} / \mathrm{ml}$ and urinary free cortisol was $30 \mu \mathrm{g} / 24 \mathrm{~h}$. Magnetic resonance (MR) scan showed a $3 \times 2.5 \mathrm{~cm}$ pituitary lesion with suprasellar extension as well as invasion of the right cavernous sinus. The lesion was hypointense on T1-weighted sequences, and markedly non-homogeneous after gadolinium administration (Fig. 1). On transsphenoidal approach, because the tumor was firm and bleeding only partial removal was possible. The patient was discharged and prescribed cortone acetate $50 \mathrm{mg}$ daily divided in three doses, fludrocortisone $50 \mu \mathrm{g}$ daily, L-thyroxine $100 \mu \mathrm{g}$ daily and testosterone enantate $250 \mathrm{mg}$ every 3 weeks. Five months after surgery, his visual field had

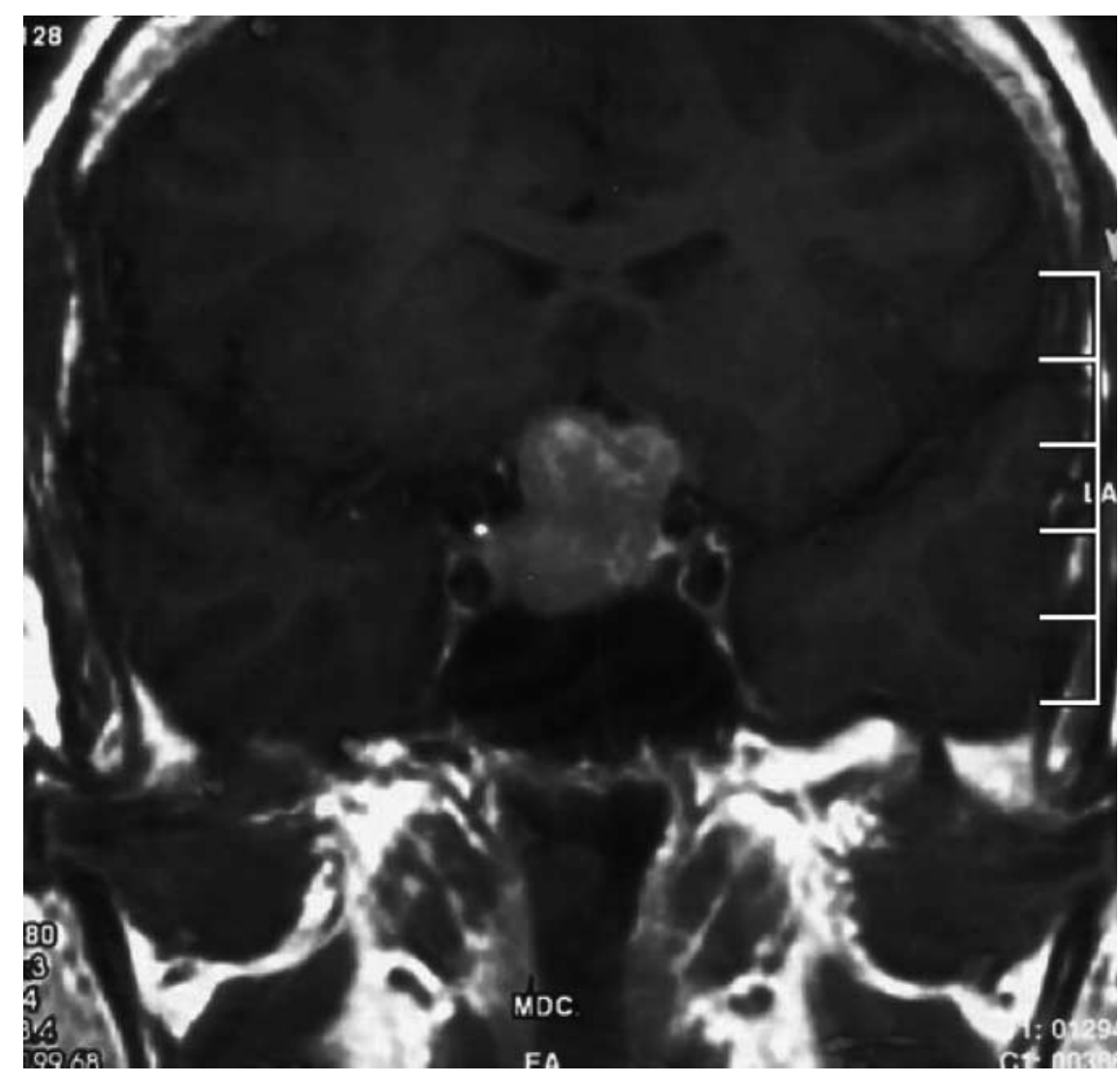

Figure $1 \mathrm{MR}$ scan after gadolinium administration. The pituitary mass was $3 \times 2.5 \mathrm{~cm}$, had suprasellar extension as well as invasion of the right cavernous sinus. The lesion was markedly non-homogeneous. 
improved but there was no fading of skin pigmentation. MR imaging (MRI) showed a large residual tumor in the suprasellar region and in the right cavernous sinus. ACTH was $2180 \mathrm{pg} / \mathrm{ml}$ at $0800 \mathrm{~h}, 602 \mathrm{pg} / \mathrm{ml}$ at $2300 \mathrm{~h}$ and suppressed to $276 \mathrm{pg} / \mathrm{ml}$ after $1 \mathrm{mg}$ of dexamethasone at midnight (for comparison, in two patients with genetically confirmed X-linked adrenal hyperplasia and normal nuclear MR (NMR) pituitary imaging, we found that $1 \mathrm{mg}$ dexamethasone overnight suppressed ACTH from 1250 and 545 to 13 and $5 \mathrm{pg} / \mathrm{ml}$ respectively). Two additional transsphenoidal operations were performed to remove the residual tumor. After the first operation, morning ACTH level was $1660 \mathrm{pg} / \mathrm{ml}$ but fell to $150 \mathrm{pg} / \mathrm{ml}$ after the second, pigmentation also disappeared. The patient was given conventional external radiotherapy, $4800 \mathrm{cGy}$, to treat a small residue in the cavernous sinus. Two years later morning ACTH concentration is now $19 \mathrm{pg} / \mathrm{ml}$ and pituitary NMR is unchanged.

\section{Pathological findings}

Histologically, the primary tumor was composed of chromophobic and basophilic neoplastic cells showing a diffuse pattern of growth. Mitoses were absent. The majority of neoplastic cells were periodic acid-Schiff (PAS) positive and expressed ACTH. No other pituitary hormone was seen. The tissue from the second operation contained bands of dense and focally hyalinized collagen and several psammomatous calcifications, which were most likely due to previous surgery. There was no normal adenohypophysis in all samples examined.

\section{Genomic analysis}

Using standard methods DNA was extracted from the blood leucocytes of both the patient and his mother. The DAX-1 gene was PCR amplified using specific primers and the PCR products were directly sequenced according to methods previously described (1). A 4 bp insertion (AGCG) at nucleotide 259, in exon 1, resulting in a frame shift and premature termination, was identified in both the patient and his mother. No other mutations were detected in the coding region.

\section{Discussion}

We have reported the first case of a patient with $\mathrm{X}$ linked adrenal hypoplasia congenita who developed an ACTH-secreting invasive macroadenoma of the pituitary gland three decades after the diagnosis of primary adrenal failure. The patient had a previously unreported $4 \mathrm{bp}$ insertion at exon 1 of the DAX-1 gene.

Our patient developed an ACTH adenoma despite glucocorticoid replacement. After the first operation, he was treated with cortone 50 daily, but this dose failed to fade skin pigmentation or reduce the size of the lesion. ACTH did not suppress after dexamethasone, and control of ACTH was only achieved after three operations and radiotherapy. Histologically, the adenoma was indistinguishable from other ACTH adenomas and there was no normal gland in surgical samples to demonstrate an accompanying hyperplasia.

In untreated primary adrenal failure the pituitary gland shows diffuse or nodular hyperplasia, tumorlets and true microadenomas (4). In a few instances, hyperplasia may mimic a tumor causing sellar enlargement and symptoms due to mass effect $(10-15)$. Hyperplasia differs from an adenoma in that it reduces or even disappears with substitution therapy although a few patients may have incomplete response to conventional replacement therapy because of the short half-life of hydrocortisone and cortone acetate or inter-individual variations of absorption and metabolism of these drugs $(16,17)$. True ACTH adenomas occur more rarely in patients with Addison's disease. Dexter et al. (6) and Jara-Albarran et al. (7) described two Addisonian patients with marked pigmentation, high serum levels without circadian rhythm of ACTH-melanocytestimulating hormone (MSH); exogenous glucocorticoids caused clinical signs of hypercortisolism without suppressing ACTH. Krautli et al. (8) reported two histologically proven ACTH adenomas in patients with Addison's disease, one of which had a symptomatic pituitary mass extending to the sphenoidal sinus. Another ACTH-secreting adenoma has been documented in a patient with generalized glucocorticoid resistance (9), giving further support to the role of glucocorticoid feedback on corticotroph proliferation and adenoma formation.

The patient reported here was found to carry a $4 \mathrm{bp}$ insertion at nucleotide 259 of the DAX-1 gene, causing a frame shift that probably prevented synthesis of a functional protein.

The DAX-1 gene is composed of two exons separated by a $3.4 \mathrm{~kb}$ intron and encodes a 470 -amino-acid protein that belongs to the orphan nuclear receptor superfamily. The NH2 terminus consists of three 66-69 repeats and is devoid of the typical zinc finger DNA binding motif. The $\mathrm{COOH}$-terminus $(273-470)$ is very similar to the ligand-binding domain (LBD) of nuclear receptors, but no specific ligand has so far been identified for this protein. The encoded protein binds to DNA hairpin structures (18) and also to RNA (19).

DAX-1 is essential for the normal development of the steroidogenic axis and sex determination. It has been shown to repress transcription of several genes expressed in the adrenal cortex and hypothalamic-pituitary-gonadal axis. In particular, DAX-1 interacts with the co-repressors N-CoR (20) and alien (21) and inhibits the transcriptional effects of steroidogenic factor-1 (SF-1) through a specific transcriptional silencing domain within the carboxyterminus $(20,22)$. All 
DAX-1 missense mutations identified in patients with $\mathrm{AHC}$ alter the protein C-terminus and impair its transcriptional repressor activity.

Patients with mutation of the DAX-1 gene present primary adrenal insufficiency in early infancy or childhood and hypogonadotropic hypogonadism during puberty. Phenotype is not correlated with genotype $(23,24)$ and different genetic and environmental factors may contribute to the 'non-classic' phenotypes reported in recent years. Adrenal failure may be transient (25), asymptomatic (26) or manifest in adulthood (27). In addition, isolated hypogonadotropic hypogonadism has been reported in a female patient (28) although, in the absence of adrenal insufficiency, DAX-1 mutations are an uncommon cause of hypogonadotropic hypogonadism or pubertal delay (29).

The role of DAX-1 in the pathogenesis of pituitary adenomas has not been established. In humans, DAX1 is expressed at the hypothalamus and pituitary gland $(30,31)$ where it regulates the transcription of LH-beta subunit, the activation of the inhibin alfa promoter and down-regulates transcriptional activity mediated by androgen and estrogen receptors (32, 33). No data are available on DAX-1 in normal ACTH-secreting cells and DAX-1 is not expressed in the AtT-20 cell line, derived from corticotropes (34). In human pituitary adenomas DAX-1 mRNA has been found in tumors of the gonadotropic lineage and in somatropic adenomas that co-secreted LH in vitro, but not in prolactinomas $(35,36)$. No data are available about expression of DAX-1 in ACTH-secreting adenomas.

In summary, we have described a pituitary ACTH adenoma in a patient with X-linked AHC due to a novel mutation of DAX-1. The reported case suggests that these patients should be carefully monitored for direct and indirect signs of pituitary adenoma, especially when a sudden rise of ACTH levels occurs despite adequate steroid substitution.

\section{Acknowledgements}

We are indebted to Dr Caterina Giannini, Department of Laboratory Medicine and Pathology, Mayo Clinic Rochester, MN, USA for helpful comments on pathological findings. This work was supported by Telethon Grant B:38, European Community UROP-BMH4 CT 969790 contract and by a grant from the 'Genomica Funzionale' project of MIUR-CNR.

\section{References}

1 Zanaria E, Muscatelli F, Bardoni B, Strom TM, Guioli G, Guo W, Lalli E, Moser C, Walker AP, McCabe ERB, Meitinger T, Monaco AP, Sassone-Corsi P \& Camerino G. An unusual member of the nuclear hormone receptor superfamily responsible for X-linked adrenal hypoplasia congenita. Nature 1994372 $635-641$.
2 Muscatelli F, Strom TM, Walker AP, Zanaria E, Recan D, Meindl A, Bardoni B, Guioli S, Zehetner G, Rabl W, Schwartz HP, Kaplan JC, Camerino G, Meitinger T \& Monaco AP. Mutations in the DAX-1 gene give rise to both X-linked adrenal hypoplasia congenita and hypogonadotropic hypogonadism. Nature 1994372 672-676.

3 Scheithauer BW, Kovacs K, Randall RV \& Ryan N. Pituitary gland in hypothyroidism. Archives of Pathology and Laboratory Medicine 1985109 499-504.

4 Scheithauer BW, Kovacs K \& Randall RV. The pituitary gland in untreated Addison's disease. Archives of Pathology and Laboratory Medicine 1983107 484-487.

5 Asa SL \& Ezzat S. The cytogenesis and pathogenesis of pituitary adenomas. Endocrine Reviews $199819798-827$.

6 Dexter RN, Orth DN, Abe K, Nicholson WE \& Liddle GW. Cushing's disease without hypercortisolism. Journal of Clinical Endocrinology $197030573-579$.

7 Jara-Albarran A, Bayort J, Caballero A, Portillo J, Laborda L, Sampedro M, Cure C \& Mateos JMP. Probable pituitary adenoma with adrenocorticotropin hypersecretion (corticotropinoma) secondary to Addison's disease. Journal of Clinical Endocrinology and Metabolism 197949 236-241.

8 Krautli B, Muller J, Landolt AM \& von Schulthess F. ACTH-producing pituitary adenomas in Addison's disease: two cases treated by transsphenoidal microsurgery. Acta Endocrinologica (Copenhagen) $198299357-363$.

9 Karl M, Lamberts SWJ, Koper JW, Katz DA, Huizenga NE, Kino T, Haddad BR, Hughes MR \& Chrousos GP. Cushing's disease preceded by generalized glucocorticoid resistance: clinical consequences of a novel, dominant-negative glucocorticoid receptor mutation. Proceedings of the Association of American Physicians 1966108 296-307.

10 Mineura K, Goto T, Yoneya M, Kowada M, Tamakawa Y \& Kagaya H. Pituitary enlargment associated with Addison's disease. Clinical Radiology 198738 435-437.

11 Dluhy R, Moore TJ \& Williams GH. Sella turcica enlargement and primary adrenal insufficiency. Annals of Internal Medicine $1978 \mathbf{8 9}$ 513-514.

12 Himsworth RL, Lewis JG \& Rees LH. A possible ACTH secreting tumour of the pituitary developing in a conventionally treated case of Addison's disease. Clinical Endocrinology (Oxford) 19789 131-139.

13 Aanderud S \& Bassøe HH. A pituitary tumour with possible ACTH and TSH hypersecretion in a patient with Addison's disease and primary hypothyroidism. Acta Endocrinolica (Copenagen) 1980 95 181-184.

14 Yanase T, Sekiya K, Ando M, Nawata H, Kato K \& Ibasyashi H. Probable ACTH-secreting pituitary tumor in association with Addison's disease. Acta Endocrinologica (Copenhagen) 1985110 $36-41$.

15 Kubota T, Hayashi M, Kabuto M, Shirasaki N, Aradachi H, Miyanaga K \& Miyabo S. Corticotroph cell hyperplasia in a patient with Addison Disease: case report. Surgical Neurology 199237 $441-447$.

16 Clayton R, Schrieber V, Burden AC \& Rosenthal FD. Secondary pituitary hyperplasia in Addison's disease. Lancet 19972 954-956.

17 Aanderud S, Myking OL \& Bassøe HH. ACTH suppression after oral administration of cortisone in Addisonian and adrenalectomized patients. Acta Endocrinologica (Copenhagen) $1982 \mathbf{1 0 0}$ $588-594$.

18 Zazopoulos E, Lalli E, Stocco DM \& Sassone-Corsi P. DNA-binding and transcriptional repression by DAX-1 blocks steroidogenesis. Nature 1997390 311-315.

19 Lalli E, Ohe K, Hindelang C \& Sassone-Corsi P. Orphan receptor DAX-1 is a shuttling RNA binding protein associated with polyribosomes via mRNA. Molecular and Cellular Biology 200020 $4910-4921$.

20 Lalli E, Bardoni B, Zazopoulos E, Wurtz JM, Strom TM, Moras D \& Sassone-Corsi P. A transcriptional silencing domain in DAX-1 whose mutation causes adrenal hypoplasia congenita. Molecular Endocrinology 199711 1950-1960. 
21 Altincicek B, Tenbaum SP, Dressel U, Thormeyer D, Renkawitz R \& Baniahmad A. Interaction of the corepresssor alien with DAX-1 is abrogated by mutations of DAX-1 involved in adrenal hypoplasia congenita. Journal of Biological Chemistry $20002757662-7667$.

22 Ito M, Yu R \& Jameson JL. DAX-1 inihibits SF-1-mediated transactivation via a carboxy-terminal domain that is deleted in adrenal hypoplasia congenita. Molecular and Cellular Biology 199717 $1476-1483$.

23 Reutens AT, Achermann JC, Ito M, Ito M, Gu W, Habiby RL, Donohoue PA, Pang S, Hindmarsh PC \& Jameson JL. Clinical and functional effects of mutations in the DAX-1 gene in patients with adrenal hypoplasia congenita. Journal of Clinical Endocrinology and Metabolism $199984504-511$.

24 McCabe ERB. Editorial: vulnerability within a robust complex system-DAX-1 mutations and steroidogenic axis development. Journal of Clinical Endocrinology and Metabolism 200287 41-43.

25 Salvi R, Gomez F, Fiaux M, Schorderet D, Jameson JL, Achermann JC, Gaillard RC \& Pralong FP. Progressive onset of adrenal insufficiency and hypogonadism of pituitary origin caused by a complex genetic rearrangement within DAX-1. Journal of Clinical Endocrinology and Metabolism 200287 4094-4100.

26 Mantovani G, Ozisik G, Achermann JC, Romoli R, Borretta G, Persani L, Spada A, Jameson JL \& Beck-Peccoz P. Hypogonadotropic hypogonadism as a presenting feature of late-onset X-linked adrenal hypoplasia congenita. Journal of Clinical Endocrinology and Metabolism $2002 \mathbf{8 7} 44-48$.

27 Tabarin A, Achermann JC, Recan D, Bex V, Bertagna X, ChristinMaitre S, Ito M, Jameson JL \& Bouchard P. A novel mutation in DAX1 causes delayed-onset adrenal insufficiency and incomplete hypogonadotropic hypogonadism. Journal of Clinical Investigation $2000105321-328$.

28 Merke DP, Tajima T, Baron J \& Cutler GB. Hypogonadotropic hypogonadism in a female caused by an X-linked recessive mutation in the DAX1 gene. New England Journal of Medicine $19993401248-1252$.

29 Achermann JC, Gu W, Kotlar TJ, Mekks JJ, Sabacan LP, Seminara SB, Habiby RL, Hindmarsh PC, Bick DP, Sherins RJ, Crowley WF, Layman LC \& Jameson JL. Mutational analysis of
DAX1 in patients with hypogonadotropic hypogonadism or pubertal delay. Journal of Clinical Endocrinology and Metabolism $1999 \mathbf{8 4}$ 4497-4500.

30 Guo W, Burris TP \& McCabe ER. Expression of DAX-1, the gene responsible for X-linked adrenal hypoplasia congenita and hypogonadotropic hypogonadism, in the hypotalamic-pituitary-adrenal/gonadal axis. Biochemical Molecular Medicine $1995 \mathbf{5 6} 8-13$.

31 Swain A, Zanaria E, Hacker A, Lovell-Badge R \& Camerino G. Mouse DAX1 expression is consistent with a role in sex determination as well as in adrenal and hypothalamus function. Nature Genetics 199612 404-409.

32 Zhang H, Thomsen JS, Johansson L, Gustafsson J \& Treuter E. DAX-1 functions as an LXXLL-containing corepressor for activated estrogen receptors. Journal of Biological Chemistry 2000 275 39855-39859.

33 Agoulnik IU, Krause WC, Bingman WE, Rahman HT, Amrikachi M, Ayala GE \& Weigel NL. Repressors of androgen and progesterone receptor action. Journal of Biological Chemistry 2003278 3136-3148.

34 Ikeda Y, Swain A, Weber TJ, Hentges KE, Zanaria E, Lalli E, Tamai KT, Sassone-Corsi P, Lovell-Badge R, Camerino G \& Parker KL. Steroidogenic factor 1 and Dax-1 colocalize in multiple cell lineages: potential links in endocrine development. Molecular Endocrinology $1996101261-1272$.

35 Ikuyama S, Mu Y, Ohe K, Nakagaki H, Fukushima T, Takayanagi R \& Nawata H. Expression of an orphan nuclear receptor DAX-1 in human pituitary adenomas. Clinical Endocrinology (Oxford) $1998 \mathbf{4 8}$ 647-654.

36 Aylwin SJB, Welch JP, Davey CL, Geddes JF, Wood DF, Besser GM, Grossman AB, Monson JP \& Burrin JM. The relationship between steroidogenic factor 1 and DAX-1 expression and in vitro gonadotropin secretion in human pituitary adenomas. Journal of Clinical Endocrinology and Metabolism 200186 2476-2483.

Received 14 April 2005

Accepted 3 May 2005 